\title{
HOUSEHOLD DEPOSITS IN THE EUROZONE AREA - NET OUTFLOWS AND HIGH VALUE DEPOSITS
}

The aim of this paper is to analyse the problem of household deposit withdrawals from monetary financial institutions in 15 Eurozone member states, and the popularity of high value deposits which are assumed as volatile in the EU post-crisis regulations. The study estimates the scale of household deposit withdrawals in 2007-2015, revealing them as a problem of two selected member states, Austria and Greece which are, however, almost invisible at the Eurozone level. It analyses the significance of high value deposits for individual populations and indicates those in which the occurrence of the deposits was the most frequent. Selected characteristics of the owners of high value deposits which may suggest their real nature are considered. The results obtained do not prove the popularity of these deposits in all the countries characterised by severe outflows between 2007-2015.

Keywords: high value household deposits, deposit net outflows, funding stability, liquidity standards, credit institutions.

DOI: $10.15611 /$ aoe.2018.2.08

\section{INTRODUCTION}

In the Eurozone, the recent years of financial and economic turmoil have restored the belief that a household propensity to accumulate deposits is a cornerstone of the stability of national economies and credit institutions. The former reliance of these entities on wholesale funding including interbank lending, had negative consequences for their resilience to liquidity shocks, and involved governments and central banks in aid programmes for private businesses.

The post-crisis regulations actively encourage a shift back to the traditional funding based on retail deposits. Under the following standards: Liquidity Coverage Ratio (LCR) and Net Stable Funding Ratio (NSFR) included in the package CRD IV/CRR (Directive 2013/36/EU of 26 June 2013; Regulation (EU) No. 575/2013 of 26 June 2013), credit institutions are required to prove the stability of their funding, leveraging the almost full potential of the deposits in the calculations of ratios. The new standards favour deposits with precise features, one of which is the single threshold of EUR

\footnotetext{
${ }^{*}$ Finance Department, Cracow University of Economics.
} 
500,000. According to the regulations, exceeding this limit makes deposits more vulnerable. However, the single threshold raises doubt about its sense due to the heterogeneity of the EU member states, expressed by different economic, financial and socio-demographic conditions, such as household wealth. Moreover, its implementation seems to be detached from the current situation since the low-interest rate environment and the loss of confidence in the banking sectors discourage individuals to hold deposits.

The aim of this paper is to assess the scale of household deposit run-offs from the monetary financial institutions (MFI) of 15 Eurozone member states in the period 2007-2015 and describe high-value household deposits which according to the post-crisis regulations are characterised by limited stability. The study answers the following research questions:

1. Were net outflows ${ }^{1}$ of household deposits coherent within the Eurozone or formed at domestic level?

2. Did high value deposits influence the MFI's liabilities from household deposits to the same extent in the analysed group of countries?

3. Who were the owners of high value deposits? Did they distinguish themselves by particular wealth, investment preferences, or socio-demographic features?

The following hypothesis is tested: during the financial and economic crises, the Eurozone member states were heterogeneous regarding the frequency and scale of household deposit net outflows as well as the prevalence of high value deposits. Thus, significant deposit withdrawals were not supported by the popularity of the deposits defined as less stable in the analysed geographic area.

The paper is organized as follows: (2) related literature; (3) regulatory approach to high-value household deposits; (4) description of the research methods and variables applied in the study; (5) the results of empirical analysis on the coherence of high-value household deposits and household deposit outflows; (6) conclusions, (7) acknowledgements.

\section{RELATED LITERATURE}

The literature on credit institutions' funding stability has identified its various aspects perceived as important during periods of stress or in the long run. However, a short history of the EU's single regulations in this respect

\footnotetext{
${ }^{1}$ Net outflows are regarded as negative values which refer to the surplus of deposit outflows over deposit inflows in a period.
} 
causes an evident lack of literature related to the sensitivity of high-value household deposits.

Existing papers discuss the role of deposits in banks' funding (Borio, 2009; Diamond and Rajan, 2001; Huang and Ratnovski, 2011), as well as their position in the financial asset portfolios of individuals (Du Caju, 2013). Moreover, the literature considers the problem of deposit withdrawals during the financial crisis (Cussen et al., 2012; Gatev et al., 2009; Pennacchi, 2006), the limits of deposit guarantees under the schemes and their impact on investors' perception of risk (Acharya and Mora, 2015; Karas et. al., 2013; Brown et al., 2014), as well as the relation between deposit outflows and loan availability (Acharya et al., 2013) or market interest rates (Acharya and Mora, 2012). Some papers analyse the deposits against the background of the saving motives of households and behaviour in cross-country comparisons, displaying them as an important component of individuals' wealth (Teppa et al., 2015). However, none of them discusses the popularity of high value deposits among populations, nor examines their influence on the credit institutions' resilience to sudden downturns on a financial market, or the longterm performance due to the short period of their existence in the EU regulations.

This paper fills the gap in the literature, introducing the category of high value deposits and initiates a discussion about their potential nature against the background of household deposit outflows during the turmoil which has been observed in the recent years.

\section{REGULATIONS REGARDING HIGH-VALUE HOUSEHOLD DEPOSITS}

In the European Union (EU), the regulatory framework for the funding stability of credit institutions was based on solutions adopted by the Basel Committee on Banking Supervision (BCBS) in December 2010 (BCBS, 2010). The Basel III Accord distinguished for LCR more stable deposits with run-off rates of $5 \%$ or $3 \%$ and less stable retail deposits with a run-off rate of $10 \%$ (BCBS, 2013). The rates were considered as minimum floors. The assignment of higher run-offs was permitted under the decision of individual jurisdictions to capture local depositors' behaviour in a period of stress. Among the less stable deposits appeared those of high value, but the BCBS did not impose for them any particular threshold (BCBS, 2013). In the document on NSFR (BCBS, 2014), retail deposits played a principal role in 
the long-term stability funding of credit institutions. This standard assumed them as available stable funding with factors of: $100 \%$ for term deposits with effective residual maturities of one year or more; $95 \%$ for stable non-maturity (demand) deposits and/or term deposits with residual maturities of less than one year provided in retail; $90 \%$ for less-stable non-maturity (demand) deposits and/or term deposits with residual maturities of less than one year provided in retail.

In the EU, the framework of regulations on credit institutions' funding stability was incorporated in the package CRDIV/CRR in 2013. The quality of funding became assessed within both liquidity standards: LCR and NSFR.

In 2013, the European Banking Authority (EBA) issued guidelines for EU credit institutions on the assessment of LCR (EBA, 2013a) with a list of factors determining higher retail deposit outflows, one of which was of extraordinary value. The document recommended considering the deposits as of "high value" if they exceed EUR 100,000 or the limit of a local deposit insurance scheme but only up to EUR $500,000^{2}$. Apart from this category, "very high value" deposits have emerged above EUR 500,000. According to the EBA, both categories should be recognised in credit institutions due to the high risk of outflows of deposit classified as the former and the very high risk of outflows of deposits from the latter.

A detailed description of stable and less stable retail (household) deposits in periods of stress was presented in 2014, under the delegated act of the European Commission (EC) (Commission Delegated Regulation (EU) 2015/61 of 10 October 2014). It points out the following characteristics of stable deposits: their coverage by deposit guarantee schemes and either (a) an established relationship with clients making withdrawals highly unlikely or (b) placement in transactional accounts. The run-off rate for these deposits became adopted at 3\%. The document presented a fixed category of less stable retail deposits as well, however their run-off rates ranged between $10 \%$ and $20 \%$. The deposits exceeding EUR 500,000 became defined as high value ones. The decision to abandon the other (lower) limit was concluded as being in the interest of simplicity (EBA, 2013b). Thus, the adopted boundary seems not to be an outcome of deep empirical analysis on the distinction between two deposit categories (stable and less stable). For that reason, the threshold may perform as an unnecessary benchmark in the assessment of credit institutions' funding stability.

\footnotetext{
${ }^{2}$ The sum of deposits placed by a particular client with one credit institution.
} 
The evolution of a regulatory stance on the adoption of the single limit of EUR 500,000 for a group of heterogeneous countries (i.e. core and peripheral) has raised doubts about its appropriateness and encouraged to conduct a comparative analysis on household deposit net outflows, and the popularity of high value deposits in the populations of individual Eurozone member states.

\section{DATA AND METHODOLOGY}

The study is conducted for 15 Euro zone countries and consists of two parts. The first one is based on aggregated data on household deposits placed with the Monetary Financial Institution (MFI) sectors and their flows in 2007-2015, which are derived from the European Central Bank (ECB) database $^{3}$. The second part is conducted on household-level data regarding high value deposits and their owners, provided by the Household Finance and Consumption Survey of the Eurosystem (HFCS) ${ }^{4}$. This database contains information collected by national central banks and statistical institutions which can be useful in the analysis of individual countries and the Eurozone (ECB, 2013) ${ }^{5}$. Table 1 presents a description of the national samples and surveying periods.

Due to the reduced number of the Eurozone member states participating in the survey, the entire study is limited to the following countries: Austria, Belgium, Cyprus, Finland, France, Germany, Greece, Italy, Luxembourg, Malta, the Netherlands, Portugal, Slovakia, Slovenia, and Spain.

The first part of the study relates to monthly flows (outflows and inflows) of household deposits in the MFI sectors of 15 Eurozone member states, in the period January 2007 - May 2015. The considered flows resulted from operations conducted by two groups of households: residents and non-residents. Due to the evolving economic and financial background of the MFIs, the time span is divided into the following sub-periods (Mody and Sandri, 2011):

- the years 2007-2008 which relate to the banking crisis;

- the years 2009-2012 characterised by the sovereign debt crisis and the evolving problems of the banking sectors as well as the economic downturn;

\footnotetext{
${ }^{3}$ See: $\mathrm{http}: / /$ sdw.ecb.europa.eu/browse.do?node $=2116082$.

${ }^{4}$ The database of restricted access. The study uses the data from the first wave of the HFCS. The second wave will be available in 2017 .

5 The standardised variables allow cross-country comparisons. See: http://www.ecb. europa.eu/pub/economicresearch/research-networks/html/researcher_hfen.en.html.
} 
- the years 2013-2015 with the further consequences of the sovereign debt crisis, the economic recession, as well as the Cypriot and Greek banking crises.

Table 1

Information about domestic samples of households from the first wave

\begin{tabular}{l|c|c}
\hline \multicolumn{1}{c|}{ Country } & $\begin{array}{c}\text { No. of households } \\
\text { surveyed }\end{array}$ & $\begin{array}{c}\text { Survey } \\
\text { period }\end{array}$ \\
\hline AT & 2,380 & $09.2010-05.2011$ \\
\hline BE & 2,327 & $04.2010-10.2010$ \\
\hline CY & 1,237 & $04.2010-01.2011$ \\
\hline DE & 3,565 & $09.2010-07.2011$ \\
\hline ES & 6,197 & $11.2008-07.2009$ \\
\hline FI & 10,989 & $01.2010-05.2010$ \\
\hline FR & 15,006 & $10.2009-02.2010$ \\
\hline GR & 2,971 & $06.2009-09.2009$ \\
\hline IT & 7,951 & $01.2010-05.2010$ \\
\hline LU & 950 & $09.2010-04.2011$ \\
\hline MT & 843 & $10.2010-02.2011$ \\
\hline NL & 1,301 & $04.2010-12.2010$ \\
\hline PT & 4,404 & $04.2010-07.2010$ \\
\hline SI & 343 & $10.2010-12.2010$ \\
\hline SK & 2,057 & $09.2010-10.2010$ \\
\hline EA & 62,522 & $11.2008-07.2011$ \\
\hline
\end{tabular}

Source: The Eurosystem HFCS.

The analysis is conducted on data which refer to MFIs. The decision about its application resulted from the lack of a relevant ECB database which focuses solely on household deposits in credit institutions. However, due to the retail character of the data applied in the study, credit institutions emerge as the most important MIFs for the allocation of household deposits.

The following quantitative monthly data regarding each country and their entire group is applied:

- the MFI sector's liabilities from household deposits (outstanding amounts at the end of monthly periods);

- household deposit flows within MFI sectors (totalled throughout the monthly periods), generated by residents and non-residents.

The data on deposit flows allows estimating net outflows which occurred at country and group levels. They represent decreases in deposits in monthly periods between 2007-2015. Net outflows can be calculated on the basis of the following formula: 


$$
D N O_{t}=D O_{t}-D I_{t} ; \quad t=1, \ldots, 101,
$$

where: $D N O_{t}$ - household deposit net outflows in period $t ; D O_{t}-$ household deposit outflows in period $t ; D I_{t}$ - household deposit inflows in period $t$. For the evaluation of the frequencies of household deposit net outflows, the months with net outflows are summed up for individual countries and the entire group.

However, not only the frequencies of net outflows are essential regarding the aim of the paper, but also their strength which displays whether these phenomena were a serious problem for domestic MFIs. The strength of net outflows in monthly periods is estimated by the following formula:

$$
x_{t}=\frac{D N O_{t}}{T D_{t-1}},
$$

where: $x_{t}$ - strength of net outflows in period $t ; D N O_{t}$ - deposit net outflows in period $t ; T D_{t-1}$ - outstanding amount of household deposits at the end of period $t-1$. Outstanding amount of household deposits at the end of the month $t-1$ represents the initial sum of deposits in period $t$ which is available for MFIs and may be subject to withdrawals. Due to the adoption of monthly data, the withdrawals of deposits placed during the same period are limited. To analyse the directions of deposit flows in individual countries, Pearson's correlation coefficient is applied.

The second part of the study is focused on high-value deposits and the features of the households who possessed them. It is based on individual quantitative and qualitative data derived from the Eurosystem HFCS.

The sets of variables are organised as follows:

1. Numerical describing the household's size (number of household members; number of members in employment), wealth (gross income; high-value deposits; value of sight deposits; value of saving deposits; value of total real assets (real estate, vehicles and valuables); value of total financial assets excluding deposits (e.g. mutual fund units, bonds, publicly traded shares);

2. Dummies referring to the household's: investment attitude (willing to take substantial financial risks while expecting to earn substantial returns; willing to take above average financial risks while expecting to earn above average returns; willing to take average financial risks to earn average returns; not willing to take any financial risks), reasons for 
saving (old-age provisions; bequests) and gift or inheritance obtainment;

3. Numerical regarding the reference person: age.

The above variables are used to identify the most common characteristics of households and reference persons, who declared the possession of high value deposits. The analysis uses descriptive statistics, i.e. arithmetic mean, median, minimum, maximum, and coefficient of variation, regarding selected household features.

Coefficient of variation $(\mathrm{CV})$ is defined as follows:

$$
C V=\frac{\sigma}{\bar{x}} 100 \%
$$

where: $\sigma$-standard deviation; $\bar{x}$-arithmetic mean.

It should be noted that the database allows identifying the households with deposits exceeding EUR 500,000, but it does not provide information on whether these sums were placed with one or more MFIs. However, it permits to analyse the respondents who were able and willing to accumulate such vast amounts on bank accounts. It should be noted that HFCS is a unique database which may give an insight in the deposit category which is beyond broadly reported traditional ones, such as overnight, redeemable at notice, or with agreed maturity.

\section{THE RESULTS OF EMPIRICAL ANALYSIS}

The first part of the study is focused on the comparison of countries regarding the frequencies and strengths of deposit net outflows from MFIs. The whole analytical period consists of 101 months.

Based on the ECB aggregated data, the countries became assessed due to the number of months with deposit withdrawals from MFIs (Figure 1). The results varied from 20 months for Germany to 47 for the Netherlands and Greece. Since the frequency of deposit evaporation was not the same in the analysed group, two sub-sets of countries were identified:

- low-frequency deposit net outflows (up to 33 months of the examined period);

- high-frequency deposit net outflows (more than 33 months of the analysed period).

The first one was formed by the minority of member states, i.e.: Belgium, Germany, Luxembourg, Malta, Portugal, and Slovakia. The second subset 
consisted of the rest of the group: Austria, Cyprus, Finland, France, Greece, Italy, the Netherlands, Slovenia, and Spain. It is worth noting that the phenomenon of withdrawals was not clearly visible at group level.

Due to the different scales of net outflows as well as the sums of household deposits placed with MFIs in the surveyed countries, the strength of withdrawals became evaluated at national and group levels. This was assessed by identifying the number of months with net outflows exceeding $1 \%$ of the outstanding amounts of household deposits. Attention was drawn to Austria and Greece whose MFI sectors were the most limited regarding the access to stable deposits due to the highest run-offs. These were the only countries characterised by double figure numbers of months with significant net outflows (Austria - 11; Greece - 23). Figure 1 presents the analysed problem in individual countries and the whole group.

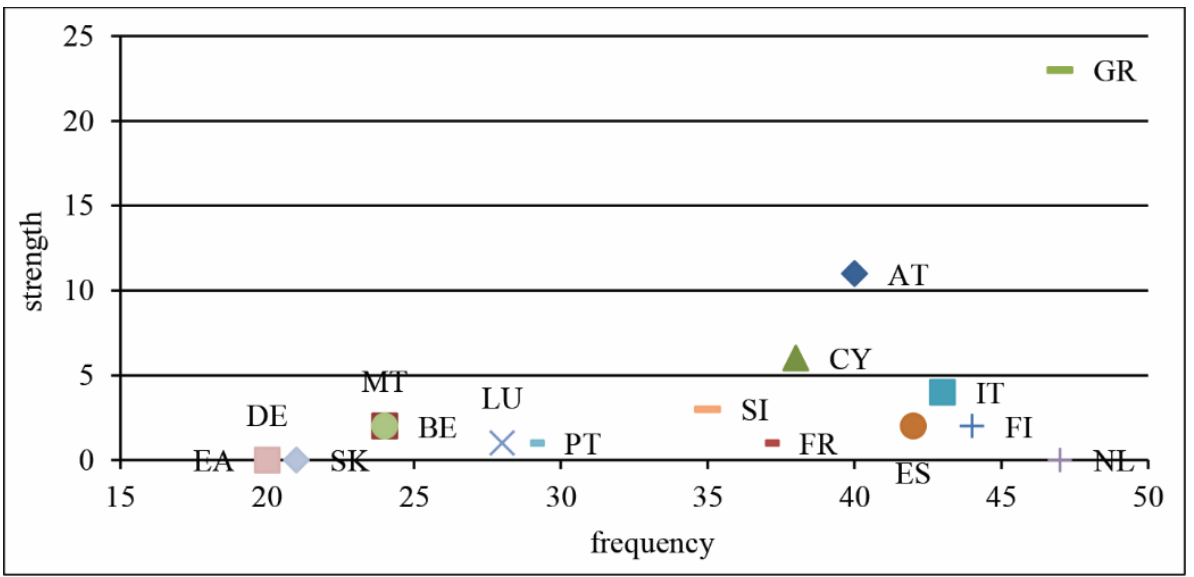

Figure 1. Frequency of net outflows (number of months with net outflows) and strength of net outflows (number of months with outflows $>1 \%$ of total household deposits) in individual countries and a whole group of countries.

Source: own study on the basis of the ECB data.

Joining the above criteria, four possible buckets of countries could be identified regarding the relevance of the analysed problem for domestic MFI sectors. These subgroups were defined as:

- low frequency and low strength of deposit net outflows: Belgium, Germany, Luxembourg, Malta, Portugal, and Slovakia;

- low frequency but high strength of deposit net outflows: none of the countries fulfilled these criteria; 
- high frequency but low strength of deposit net outflows: Cyprus, Finland, France, Italy, the Netherlands, Slovenia, and Spain;

- high frequency and high strength of deposit net outflows: Austria and Greece.

However, the above analysis does not take into consideration the severe volatility of the households and MFIs environments in the extended time span, lasting from January 2007 to May 2015. Implementing the sub-periods defined by Mody and Sandri (2011), significant developments in deposit run-offs were identified (Table 2). In some countries, the evolving turmoil exacerbated the frequency of deposit net outflows. This phenomenon was identified in Austria, Cyprus, Finland, the Netherlands, Portugal, Slovenia, and Spain. It should be noted that all of them except for Austria and Portugal, were classified into the third bucket of countries characterised by high frequency and low strength of net outflows. For the analysis of the strength of net outflows (the second dimension) in the sub-periods, the shares of months characterised by net outflows exceeding $1 \%$ of the outstanding amounts of deposits were estimated (Table 2). The results showed that Austria, Cyprus, Finland, Luxembourg and Malta were the Eurozone member states in which the evolving destabilisation led to increasing run-offs. The analysis conducted in individual sub-periods negatively highlighted selected countries regarding both criteria, i.e. Austria, Cyprus and Finland. The continuation of the presented tendencies in these member states may limit access to stable funding for local MFIs in the future. The data also displayed the significance of the analysed problem for the Greek sector. Despite its reduction in the last sub-period, the percentages characterising this country proclaimed it as a negative leader.

Table 2

Sub-periods (\%) with deposit net outflows in the Eurozone countries

\begin{tabular}{|c|c|c|c|c|c|c|c|c|c|c|c|c|c|c|c|}
\hline \multirow{2}{*}{$\begin{array}{c}\text { Sub- } \\
\text { periods }\end{array}$} & \multicolumn{15}{|c|}{ Frequency of net outflows } \\
\hline & $\mathrm{AT}$ & $\mathrm{BE}$ & $\mathrm{CY}$ & $\mathrm{DE}$ & ES & FI & FR & GR & IT & $\mathrm{LU}$ & MT & NL & PT & SI & SK \\
\hline $2007-2008$ & $25 \%$ & $33 \%$ & $4 \%$ & $25 \%$ & $17 \%$ & $13 \%$ & $33 \%$ & $13 \%$ & $33 \%$ & $8 \%$ & $17 \%$ & $29 \%$ & $13 \%$ & $17 \%$ & $0 \%$ \\
\hline $2009-2012$ & $38 \%$ & $21 \%$ & $27 \%$ & $17 \%$ & $48 \%$ & $52 \%$ & $40 \%$ & $58 \%$ & $48 \%$ & $38 \%$ & $38 \%$ & $46 \%$ & $27 \%$ & $40 \%$ & $29 \%$ \\
\hline $\begin{array}{l}\text { 2013-2015 } \\
\text { May }\end{array}$ & $55 \%$ & $21 \%$ & $83 \%$ & $21 \%$ & $52 \%$ & $55 \%$ & $34 \%$ & $55 \%$ & $41 \%$ & $24 \%$ & $7 \%$ & $62 \%$ & $45 \%$ & $41 \%$ & $24 \%$ \\
\hline $\begin{array}{c}\text { Sub- } \\
\text { periods }\end{array}$ & \multicolumn{15}{|c|}{ Strength of net outflows } \\
\hline $2007-2008$ & $0 \%$ & $8 \%$ & $0 \%$ & $0 \%$ & $0 \%$ & $0 \%$ & $0 \%$ & $0 \%$ & $8 \%$ & $0 \%$ & $0 \%$ & $0 \%$ & $0 \%$ & $8 \%$ & $0 \%$ \\
\hline $2009-2012$ & $13 \%$ & $0 \%$ & $0 \%$ & $0 \%$ & $4 \%$ & $2 \%$ & $2 \%$ & $35 \%$ & $4 \%$ & $0 \%$ & $2 \%$ & $0 \%$ & $2 \%$ & $0 \%$ & $0 \%$ \\
\hline $\begin{array}{l}\text { 2013-2015 } \\
\text { May }\end{array}$ & $17 \%$ & $0 \%$ & $21 \%$ & $0 \%$ & $0 \%$ & $3 \%$ & $0 \%$ & $21 \%$ & $0 \%$ & $3 \%$ & $3 \%$ & $0 \%$ & $0 \%$ & $3 \%$ & $0 \%$ \\
\hline
\end{tabular}

Source: own calculations derived from the ECB data. 
As presented above, the problem of deposit net outflows could be assessed as important only in selected countries. At the Eurozone level, it blurred due to certain reasons. One of them might be opposing tendencies in deposit accumulation among households caused by the heterogeneous economic and financial condition of countries or cross-border deposit transfers. To verify the compliance of directions of deposit flows ${ }^{6}$ within individual countries and identify discrepancies in this regard in the period: January 2007 - May 2015, Pearson's correlation coefficients were estimated.

Regarding the first reason, the tendencies in deposit flows were assessed with data referring to the operations conducted by residents in individual countries. The outcomes confirmed the occurrence of flows of opposing directions within the Eurozone. Such phenomenon could be observed between: Austria and the Netherlands $(r=-0.28)$; France and the Netherlands $(r=-0.23)$; Greece and the Netherlands $(r=-0.28)^{7}$. Thus, a decrease in total household deposits in one country was accompanied by an increase in their aggregated value in the other.

The results regarding the possible occurrence of the second motive were based on deposit flows generated by non-residents in each member state. The negative, statistically significant coefficients ${ }^{8}$ showed the opposing directions of the flows during the period analysed in selected countries. The greatest inconsistencies in this regard were identified between the German MFIs and the following sectors: Greek $(\mathrm{r}=-0.45)$ and Italian $(\mathrm{r}=-0.31)$. It should be noted that the German sector was defined as one of low frequency and low strength of deposit net outflows, thus there was a reason to perceive it as a possible safe haven for deposits initially placed with the entities from peripheral countries. The same could be observed between the Dutch sector which was characterised by net outflows of high frequency but low strength, and the MFI sectors from peripheral countries like Spain $(\mathrm{r}=-0.36)$, Greece $(\mathrm{r}=-0.34)$ and Italy $(r=-0.28)$. The most significant opposing directions of the flows were found between Greece and the following: Austria ( $\mathrm{r}=-0.29)$, Cyprus $(\mathrm{r}=-0.61)$, Germany $(\mathrm{r}=-0.45)$, Malta $(\mathrm{r}=-0.54)$, the Netherlands $(\mathrm{r}=-0.34)$ and Slovenia $(\mathrm{r}=-0.29)$.

The first part of the study disclosed that household deposit net outflows were formed in an individual manner in the analysed euro area member states.

\footnotetext{
${ }^{6}$ They are net flows. Net flows are positive when inflows exceed outflows or negative when inflows are lower than outflows in a particular period of time.

${ }^{7}$ Statistically significant correlation coefficients $(\alpha \leq 0.05)$.

${ }^{8}$ Ibidem.
} 
The problem appeared as the most severe for the Austrian and Greek MFI sectors and potentially difficult for the Cypriot and Finnish ones when taking into consideration the sub-periods, however at group level the problem was mitigated. The above outcomes raise doubt about the sense of the harmonisation of rules relating to the assessment of the stability of retail deposits for a group of different countries. The results encouraged to analyse a new regulatory category of high value deposits which became announced as volatile, to test whether its popularity occurred in the countries where net outflows have arisen as the significant problem.

In the second part of the study, an attempt was made to evaluate the significance of high-value deposits for households in individual countries, and thus their availability for domestic MFIs. Moreover, it tried to identify household features which might indicate the real nature of these deposits. The analysis was based on individual households' data from the Eurosystem HFCS.

The data revealed the slight popularity of high-value deposits among households in the Eurozone. Moreover, in the Slovakian and Slovenian samples these deposits were not identified. Some countries were characterised by the insufficient number of households with large deposits (Greece, Malta, the Netherlands, and Portugal). In the case of these member states, the results should not be generalised. However, their presence in the study allowed assessing whether the circumstances of the deposits' occurrence were like those observed in other countries which could be considered as regularities. In the remaining member states, households with high value deposits constituted up to $2 \%$ of all the samples surveyed. The largest fraction occurred in Spain. It should be noted that these percentages were in line with the shares of all high value deposits in household deposit totals reported in the domestic samples (Figure 2). However, the impact of high value deposits on overall household deposits could be assessed as significant in selected member states. In Spain, they constituted $41.3 \%$ of the aggregated value of deposits declared by all the households surveyed, in Belgium - 25.9\%, in Luxembourg $-22.7 \%$. The shares ranging from $10 \%$ to $15 \%$ were characteristic for the Austrian, Cypriot, French, and Portuguese samples. The above percentages inclined to recognise the importance of high value deposits for the funding stability of selected MFI sectors. However, these outcomes did not fully map the results from the first part of the study. Thus, they motivated us to inquire into the features of high value deposit owners, which may suggest the real nature of the deposits - stable or unstable - in individual Eurozone member states. 


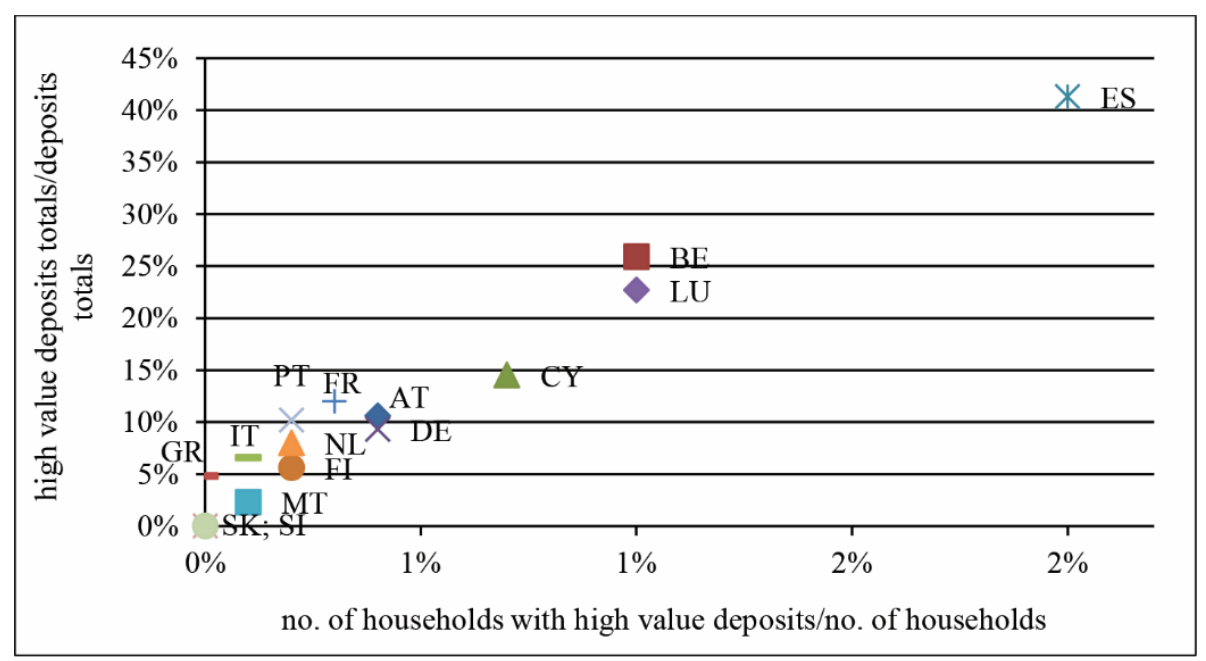

Figure 2. The sum of high value deposits in household deposit totals (\%) and number of households with high value deposits in the total number of households surveyed (\%) in individual countries and a whole group

Source: own study on the basis of the Eurosystem HFCS.

In the Eurozone countries, high value deposits were diversified regarding their levels (Table 3). This heterogeneity was displayed in the values of the coefficient of variation (CV), which ranged from $12 \%$ to $124 \%$. The highest were obtained for Belgium and Luxembourg, and the lowest for Cyprus and Finland. The median levels of high value deposits varied from EUR 550, 000 in Cyprus to EUR 833,357 in Spain. Almost everywhere the minimum levels were close to the adopted threshold, while the maximum were spread from EUR 700,000 in Cyprus to EUR 7,050,000 in Spain.

Part of the above cross-country diversity of the deposits could be a result of the heterogeneity of households regarding their selected features like the size, the wealth, the declared risk attitude or saving aims, as well as the age of the respondent. The characteristics which might be useful for the identification of the real nature of high value deposits are summarised in Tables 4-5. In 13 countries (excluding Slovakia and Slovenia), the average number of household members varied from two to three persons, but more than one person in employment was characteristic for only a few of them. From all the variables which describe household attitudes to financial risk, the most frequently declared were the willingness to take an average level of risk and the lack of willingness to take any risk. These attitudes may suggest the stable character of high value deposits due to households' unwillingness to reallocate funds 
Table 3

Summary statistics of high value deposits in households in selected Eurozone countries

\begin{tabular}{|c|c|c|c|c|c|c|c|c|}
\hline \multirow{3}{*}{ Country } & \multirow{3}{*}{$\begin{array}{c}\text { No. } \\
\text { of obs. }\end{array}$} & \multicolumn{7}{|c|}{ Household deposits* } \\
\hline & & \multicolumn{5}{|c|}{ High value deposits } & \multirow{2}{*}{$\begin{array}{c}\begin{array}{c}\text { Sight } \\
\text { deposits }\end{array} \\
\text { Mean }\end{array}$} & \multirow{2}{*}{$\begin{array}{c}\begin{array}{c}\text { Saving } \\
\text { deposits }\end{array} \\
\text { Mean }\end{array}$} \\
\hline & & Mean & Median & Min & Max & $\mathrm{CV}^{* *}$ & & \\
\hline AT & 9 & 791,853 & 630,200 & 527,000 & $1,444,834$ & 45 & 49,957 & 741,896 \\
\hline$\overline{\mathrm{BE}}$ & 25 & $1,162,651$ & 620,800 & 500,000 & $5,003,000$ & 107 & 132,085 & $1,030,566$ \\
\hline $\mathrm{CY}$ & 9 & 561,144 & 550,000 & 500,000 & 700,000 & 12 & 72,255 & 488,889 \\
\hline $\mathrm{DE}$ & 13 & 846,154 & 603,000 & 500,001 & $2,550,000$ & 69 & 86,615 & 759,538 \\
\hline ES & 118 & $1,066,683$ & 833,357 & 500,000 & $7,050,000$ & 80 & 275,905 & 790,778 \\
\hline FI & 18 & 670,661 & 599,159 & 588,409 & 820,831 & 16 & 670,661 & $* * * *$ \\
\hline FR & 51 & 924,385 & 762,114 & 500,600 & $2,683,490$ & 45 & 577,374 & 347,010 \\
\hline GR & 1 & $1,300,000$ & $* * *$ & $* * *$ & $* * *$ & $* * *$ & $1,300,000$ & 0 \\
\hline IT & 10 & 723,757 & 607,187 & 501,484 & $1,226,905$ & 37 & 409,161 & 314,596 \\
\hline LU & 12 & $1,093,965$ & 606,809 & 515,000 & $5,286,768$ & 124 & 119,252 & 974,713 \\
\hline MT & 1 & 515,142 & $* * *$ & $* * *$ & $* * *$ & $* * *$ & 15,141 & 500,001 \\
\hline $\mathrm{NL}$ & 2 & $1,731,256$ & $* * *$ & 597,012 & $2,865,500$ & $* * *$ & 5,251 & $1,726,006$ \\
\hline PT & 7 & $1,065,571$ & 787,500 & 516,000 & $1,935,000$ & 57 & \begin{tabular}{l|}
77,571 \\
\end{tabular} & 988,000 \\
\hline EA & 276 & 979,816 & 700,247 & 500,000 & $7,050,000$ & 80 & 315,196 & 710,989 \\
\hline
\end{tabular}

$*$ in EUR; ** in \%; *** the number of responding households was too small to estimate the statistics; $* * * *$ no data available.

Source: own calculations derived from the Eurosystem HFCS.

Table 4

Summary statistics of selected household characteristics in the Eurozone countries

\begin{tabular}{|c|c|c|c|c|c|c|c|c|c|c|c|c|}
\hline & \multirow{3}{*}{$\begin{array}{l}\dot{n} \\
\stackrel{0}{0} \\
\stackrel{+}{0} \\
\dot{0} \\
\dot{z}\end{array}$} & \multicolumn{11}{|c|}{ Household characteristics } \\
\hline & & & $\begin{array}{l}\text { No. of } \\
\text { useho } \\
\text { ember } \\
\text { nean) }\end{array}$ & & \multicolumn{2}{|c|}{ Risk attitude } & \multicolumn{4}{|c|}{ Gross income* } & \multicolumn{2}{|c|}{ Saving aims } \\
\hline & & 胥 & $\begin{array}{l}\overrightarrow{0} \\
\stackrel{0}{0} \\
\stackrel{0}{0} \\
\text { |⿱㇒士刂 }\end{array}$ & 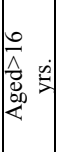 & 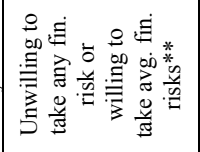 & 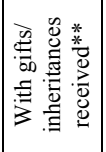 & 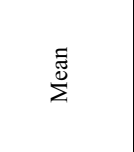 & 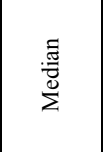 & $\stackrel{\Xi}{\Sigma}$ & $\stackrel{\circlearrowright}{\stackrel{\varpi}{\Sigma}}$ & 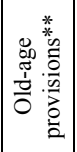 & 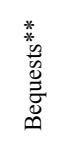 \\
\hline AT & 9 & 3 & 1 & 3 & 33 & 78 & 215,177 & 100,500 & 53,401 & 515,762 & 78 & 22 \\
\hline $\mathrm{BE}$ & 25 & 2 & 0 & 2 & 76 & 32 & 87,005 & 76,320 & 18,100 & 310,000 & 48 & 36 \\
\hline $\mathrm{CY}$ & 9 & 3 & 2 & 3 & 89 & 67 & 151,734 & 91,000 & 55,050 & 432,000 & 56 & 22 \\
\hline $\mathrm{DE}$ & 13 & 2 & 1 & 2 & 92 & 62 & 432,088 & 336,000 & 49,000 & $1,350,000$ & 54 & 0 \\
\hline ES & 118 & 2 & 1 & 2 & 92 & 67 & 375,621 & 108,349 & 0 & $8,760,318$ & 19 & 11 \\
\hline FI & 18 & 2 & 2 & 2 & $* * * *$ & $* * * *$ & 265,666 & 12,683 & 85,425 & $1,080,636$ & $* * * *$ & $* * * *$ \\
\hline FR & 51 & 2 & 0 & 2 & $* * * *$ & 69 & 236,388 & 125,848 & 18,822 & $1,833,944$ & $* * * *$ & $* * * *$ \\
\hline GR & 1 & 3 & 2 & 2 & 0 & 0 & $2,110,000^{*}$ & $* * *$ & $* * * *$ & $* * *$ & 0 & 0 \\
\hline IT & 10 & 2 & 1 & 2 & 70 & ***** & 87,234 & 79,068 & 9,531 & 194,300 & $* * * *$ & $* * * *$ \\
\hline LU & 12 & 3 & 1 & 3 & 100 & 50 & 252,234 & 250,100 & 31,200 & 520,560 & 42 & 42 \\
\hline MT & 1 & 2 & 0 & 2 & 100 & 0 & $51,000^{*}$ & $* * *$ & $* * *$ & $* * *$ & 0 & 100 \\
\hline NL & 2 & 2 & 1 & 2 & 100 & 0 & $185,861^{*}$ & $* * *$ & 128,734 & 242,988 & 100 & 100 \\
\hline PT & 7 & 3 & 2 & 2 & 86 & 29 & 189,660 & 125,000 & 38,930 & 604,600 & 33 & 33 \\
\hline EA & 276 & 2 & 1 & 2 & 64 & 55 & 289,909 & \begin{tabular}{|l|}
122,741 \\
\end{tabular} & 0 & $8,760,318$ & 23 & 13 \\
\hline
\end{tabular}

* in EUR, from last 12 months; ** \% of households surveyed; *** the number of responding households was too small to estimate the statistics; **** no data available.

Source: own calculations derived from the Eurosystem HFCS. 
Table 5

Summary statistics of households' wealth in selected Eurozone countries

\begin{tabular}{|c|c|c|c|c|c|c|c|c|c|}
\hline & \multirow{3}{*}{$\begin{array}{c}\text { No. } \\
\text { of } \\
\text { obs. }\end{array}$} & \multicolumn{8}{|c|}{ Households' wealth } \\
\hline & & \multicolumn{4}{|c|}{ Total financial assets (excluding deposits)* } & \multicolumn{4}{|c|}{ Total real assets* } \\
\hline & & Mean & Median & Min & $\operatorname{Max}$ & Mean & Median & Min & Max \\
\hline AT & 9 & 983,046 & 944,798 & 617,784 & $1,448,877$ & $1,404,053$ & 870,000 & 499,747 & $3,412,000$ \\
\hline $\mathrm{BE}$ & 25 & 684,117 & 400,750 & 0 & $2,100,000$ & $1,266,706$ & 574,500 & 0 & $6,402,814$ \\
\hline $\mathrm{CY}$ & 9 & 565,327 & 139,444 & 500 & $3,100,000$ & $7,579,859$ & $6,492,000$ & $2,674,169$ & $13,065,000$ \\
\hline $\mathrm{DE}$ & 13 & $2,812,856$ & $1,040,000$ & 600,000 & $13,555,000$ & $6,402,577$ & $1,804,000$ & 685,000 & $62,750,000$ \\
\hline ES & 118 & $1,656,513$ & 253,389 & 0 & $33,000,000$ & $7,065,044$ & $1,964,102$ & 128,400 & $94,003,000$ \\
\hline FI & 18 & 265,376 & 251,591 & 7,503 & 651,102 & $1,620,517$ & 721,795 & 148,828 & $11,225,655$ \\
\hline FR & 51 & 703,298 & 275,558 & 0 & $4,427,245$ & $1,701,840$ & $1,175,115$ & 33,593 & $16,397,098$ \\
\hline GR & 1 & 300,000 & $* * *$ & $* * *$ & $* * *$ & $10,100,000$ & $* * *$ & $* * *$ & $* * *$ \\
\hline IT & 10 & 288,503 & 22,500 & 0 & $1,762,784$ & $1,098,864$ & 572,000 & 72,000 & $5,540,000$ \\
\hline $\mathrm{LU}$ & 12 & \begin{tabular}{l|l|}
375,582 \\
\end{tabular} & 150,205 & 0 & $1,580,133$ & $2,190,750$ & \begin{tabular}{|l|}
$1,460,000$ \\
\end{tabular} & 453,500 & $5,877,000$ \\
\hline MT & 1 & 872,058 & $* * *$ & $* * *$ & $* * *$ & 25,000 & $* * *$ & $* * *$ & $* * *$ \\
\hline NL & 2 & 665,613 & $* * *$ & \begin{tabular}{|l|}
$1,010,780$ \\
\end{tabular} & 320,446 & 377,258 & $* * *$ & 225,000 & 529,516 \\
\hline PT & 7 & 550,679 & 143,750 & 0 & $2,498,000$ & $5,796,214$ & \begin{tabular}{|l|}
$1,900,000$ \\
\end{tabular} & 210,300 & 210,300 \\
\hline EA & 276 & $1,084,573$ & 255,764 & 0 & $33,000,000$ & $4,483,733$ & $1,424,852$ & 0 & $94,003,000$ \\
\hline
\end{tabular}

Source: own calculations derived from the Eurosystem HFCS.

into riskier assets available on the retail financial market. In such a case, they would negate the appropriateness of the regulatory opinion regarding their nature. The long-term character of the deposits could also be recognised in the most frequently declared household saving aims, old-age provisions and bequests. The samples of households surveyed were characterised by varying wealth, described by the values of the real and financial assets possessed. It should be noted that the financial situation of a significant part of the households resulted from gifts and inheritances received in the past, thus it was not the effect of wise, risky investment in the past. The deposits appeared dominant in the average financial asset portfolios of households in the majority of the member states - Belgium, Finland, France, Greece, Italy, Luxembourg, the Netherlands, and Portugal. Moreover in all these countries, except for the Netherlands, households with high value deposits possessed on average more real assets than financial assets (except deposits), proving the truthfulness of the declared attitudes to risks. These investments might be perceived as relevant information regarding households' focus on assets which are free from financial risks, e.g. real estate, vehicles, or valuables, rather than mutual fund units, bonds, shares, etc. The low-volatility nature of high value deposits in a longer time horizon was also suggested by the average age of the reference persons together with the most popular declared saving aims. The mean age varied between the countries 
from 41 to 66 years old and was lower than the retirement age after the corrections which were adopted in recent years. As presented above, certain commonly occurring features may support the belief about the reluctance of large deposits to sudden withdrawals from credit institutions or their allocation in alternative assets on financial markets.

\section{CONCLUSIONS}

The lessons learnt from the last financial crisis have emphasised the importance of the funding stability of credit institutions for their resilience to liquidity shocks. The modified and expanded EU regulations include detailed solutions, such as a limit of EUR 500,000 for household deposits regarded as stable. However, they may appear as ineffective in a group of countries which are heterogeneous. The adopted limit is not related to the minimum level of unguaranteed retail deposits nor the allocation capabilities of households from the poorest countries in the group, like Slovakia or Slovenia.

The net outflows of household deposits in the period 2007-2015 appeared as a problem of varying importance for the analysed countries due to their different frequencies and strengths. The examined issue seemed particularly severe for the Austrian and Greek MFI sectors. The identification of subperiods representing different phases of the turbulence revealed this problem as potentially grave for Cyprus and Finland. The data aggregated at the Eurozone level contributed to blurring of net outflows. This might result from opposing household tendencies in ownership of deposits - individuals in some member states could be more willing to place deposits, while in the others more prone to deposit withdrawals. The lack of compliance of the directions of deposit flows in the Netherlands and three other countries (Austria, Greece and France) may suggest such a problem. The second reason might be crosscountry deposit flows. The German MFI sector, as well as the Dutch, could be perceived as a safe haven for individuals who decided to withdraw deposits from peripheral member states. The opposing directions of deposit flows were identified regarding these countries and for example Greece, Italy, or Spain. Thus, the results of the first part of the study negated the same manner of formation of deposit net outflows at the Eurozone level.

The popularity of high value deposits significantly varied among households residing in the group of analysed countries. The percentages of respondents who declared their possession were small and ranged up to $2 \%$. However, in Belgium, Luxembourg, and Spain high value deposits formed from $23 \%$ to $41.3 \%$ of all deposits declared by households. The shares ranging 
from $10 \%$ to $15 \%$ characterised the Austrian, Cypriot, French, and Portuguese samples. The above percentages allowed to assume the importance of high value deposits as a funding for the above MFI sectors. Moreover, the quality of these deposits seems not to be poor in practice. The data allowed for identifying the features of households and reference persons which suggested the longer-term nature of high value deposits, as well as the lack of interest in replacing them with risky financial assets. These were for example an aversion to increased financial risks, saving aims related to the distant future of respondents who did not meet the retirement criteria, focus on real assets instead of financial ones, and/or the important position of deposits among other financial assets of the households.

Concluding, the geographic area of the increased net outflows did not cover all the countries characterised by the significance of high value deposits. The results obtained from the study indicated Austria and Cyprus as the member states in which both issues could be linked. Due to this reason, it is worth identifying additional deposit categories which are sensitive to withdrawals under turbulent conditions.

\section{REFERENCES}

Acharya, V., Almeida, H., Campello, M., Aggregate Risk and the Choice between Cash and Lines of Credit, "The Journal of Finance", 68, pp. 2059-2116, 2013.

Acharya, V., Mora, N., A Crisis of Banks as Liquidity Providers, "The Journal of Finance", vol. 70, issue 1, pp. 1-43, 2015.

Acharya, V., Mora N., Are Banks Passive Liquidity Backstops? Deposit Rates and Flows During the 2007-2009 Crisis, NBER Working Paper, no 17838, pp. 1-63, 2012.

BCBS, Basel III: A Global Regulatory Framework for More Resilient Banks and Banking Systems, Bank for International Settlements, Basel, 2010.

BCBS, Basel III: The Liquidity Coverage Ratio and Liquidity Risk Monitoring Tools, Bank for International Settlements, Basel, 2013.

BCBS, Basel III: The Net Stable Funding Ratio, Bank for International Settlements, Basel, 2014.

Borio, C., Ten Propositions about Liquidity Crises, BIS Working Paper, no 293, pp. 1-21, 2009.

Brown, M., Guin, B., Morkoetter, S., Deposit Withdrawals from Distressed Commercial Banks, Swiss Institute of Banking and Finance Working Papers on Finance, 19, pp. 1-33, 2014.

Commission Delegated Regulation (EU) 2015/61 of 10 October 2014 to supplement Regulation (EU) No 575/2013 of the European Parliament and the Council with regard to liquidity coverage requirement for Credit Institutions, OJ L 11 of 17 January 2015.

Cussen, M., O'Leary, B., Smith, D., The Impact of the Financial Turmoil on Households: A Cross Country Comparison, Central Bank of Ireland - Quarterly Bulletin, 02 / April, pp. 78-98, 2012. 
Diamond, D. W., Rajan, R. G., Banks and Liquidity, “American Economic Review”, 91(2), pp. 422-425, 2001.

Du Caju, P., Structure and Distribution of Household Wealth: An Analysis Based on the HFCS, "National Bank of Belgium Economic Review", September, pp. 41-62, 2013.

EBA, Guidelines on retail deposits subject to different outflows for purposes of liquidity reporting under Regulation (EU) No 575/2013, on prudential requirements for credit institutions and investment firms and amending Regulation (EU) No 648/2012 (Capital Requirements Regulation - CRR), European Banking Authority, London, 2013a.

EBA, EBA Discussion Papers on Defining Liquid Assets in the LCR under the draft CRR and on retail deposits subject to higher outflows for the purposes of liquidity reporting, European Banking Authority, London, 2013b.

ECB, The Eurosystem Household Finance and Consumption Survey Results from the First Wave, Statistics Paper Series, 2/2013, pp. 1-112.

Gatev, E., Schuermann, T., Strahan, P., Managing Bank Liquidity Risk: How Deposit-Loan Synergies Vary with Market Conditions, "Review of Financial Studies", 22, pp. 995$-1020,2009$.

Huang, R., Ratnovski, L., The Dark Side of Bank Wholesale Funding, "Journal of Financial Intermediation”, 20, pp. 248-263, 2011.

Karas, A., Pyle, W., Schoors, K., Deposit Insurance, Banking Crises, and Market Discipline: Evidence from a Natural Experiment on Deposit Flows and Rates, "Journal of Money, Credit and Banking", vol. 45, no 1, pp. 179-200, 2013.

Mody, A., Sandri, D., The Eurozone Crisis: How Banks and Sovereigns Came to be Joined at the Hip, IMF Working Paper, 11/269, pp. 1-33, 2011.

Pennacchi, G., Deposit Insurance, Bank Regulation, and Financial System Risks, "Journal of Monetary Economics", 53, pp. 1-30, 2006.

Regulation (EU) No 575/2013 of the European Parliament and of the Council of 26 June 2013 on prudential requirements on credit institutions and investment firms and amending Regulation (EU) No 648/2012, OJ L 176 of 27 June 2013.

Teppa, F., Porpiglia, A., Ziegelmeyer, M., Le Blanc, J., Zhu, J., Household Saving Behaviour and Credit Constraints in the Euro Area, European Central Bank Working Paper, 1790, pp. 1-62, 2015.

Received: January 2016, revised: November 2016

Acknowledgements: This research has been supported by the National Science Centre in Poland (grant No. DEC-2013/11/D/HS4/04056). Part of the study was based on the data provided by the Eurosystem Household Finance and Consumption Survey. 